\title{
Sustainability intent transforming staple food in the Greater Mekong Sub-region: Qualitative study of Low Input and Niche Rice Value Chain
}

\author{
Piya Ngamcharoenmongkol \\ NIDA Business School, National Institute of Development Administration \\ Bangkok, Thailand \\ Salil K Sen \\ Sustainability Management School, Geneva, Switzerland and \\ Institut Mines-Telecom Business School, Evry, France and \\ NIDA Business School, NIDA, Bangkok, Thailand \\ Viput Ongsakul \\ NIDA Business School, National Institute of Development Administration (NIDA) \\ Bangkok, Thailand
}

\section{Keywords}

Low input niche rice value chain; staple food Heritage rice-cuisine-based sustainable entrepreneurship; East - West Economic Corridor, sustainable use of resources; Cambodia - Laos Myanmar - Vietnam - Thailand; Hierarchical Bayes

\begin{abstract}
Low-input, niche rice value chain in contexts of Cambodia, Myanmar, Thailand and Vietnam has potential for sustainability intent to transform the Greater Mekong agri-retail consumer behavior. Creative communications for Sustainability or true-green advertising framework test-beds input-side optimization through rationalization of scaled-down water and off-grid-energy. This paper builds on retail mindset that drives sustainability intent, proactively. The research probes the research gap on lack of co-evolution of ruralurban aligned, rurbanization, through hierarchical levels of three sets of metrices of entrepreneurial potential. Literature prompts that the latent spirit of ownership evolves from trust. The potential of shared value entrepreneurship is a possibility for heritage rice-cuisine-driven family-led bottom-up businesses. To galvanize this spirit of ownership for folklore rice-based culinary delights spanning Cambodia, Laos, Myanmar, Vietnam and Thailand (CLMVT) is an interesting proposition. The vibrant Eastern Economic Corridor (EEC) is the test-bed here and this paper unfurls the theory leading to practice on issues of sustainability amid disaster vulnerability, floods, droughts and climate disruption. Key take-aways are (i) low input niche rice value chain serves as a sustainability enabler of tourism pivoted through heritage culinary traditions (ii) entrepreneurial ventures at community-scale can integrate the folklore heritage rice-cuisinedriven tourism with economic infrastructure of EEC through the spirit of ownership. Hierarchical Bayesbased sustainable entrepreneurship metric assesses the viability.
\end{abstract}

Corresponding author: Piya Ngamcharoenmongkol

Email addresses for the corresponding author:dr.piya.n@hotmail.com

First submission received: $9^{\text {th }}$ October 2018

Revised submission received: $6^{\text {th }}$ December 2018

Accepted: 18 th January 2019

\section{Introduction}

The spirit of ownership evolves from trust. Given the literature supported interfirm familial networks to sustain entrepreneurship, this paper proposes 'rurbanization' to galvanize the spirit of ownership for heritage cuisine for Cambodia, Laos, Myanmar, Vietnam and Thailand (CLMVT). The paper contributes to the EEC to usher rural - urban connect, described here as rurbanization, through heritage culinary tourism. The value proposition secures sustainable use of resources as it addresses a vital research gap for blending rural with urban tourist destinations. The outcome of this paper blends tourism leveraged on heritage rice-based multi-cuisine in C-L-M-V-T given the milieu of habitat development through EEC. The added feature is to posit low resource input niche rice value chain, that 
would nurture heritage for well-being. The EEC infrastructural fabric is predominantly rural with rapid clustering urban hot-spots. Hierarchical Bayes assesses the viability of the blend. A notable concern for EEC is unpredictable and exacerbating issues on disaster preparedness, floods, droughts and disruption. Tourism when parenthesized with heritage cuisine, draws not only economic largesse but generates emotive feelings, such as, care for rural - urban blended development. These characteristics open the relevance for heritage cuisine tourism. The pilot outcome based justifies the proposed methodological framework, with the Sustainable Heritage-cuisine tourism Intent metric (significance 0.004) meeting the likelihood ratio tests.

The key to retain transformation in this era of resource optimization is continuous improvement. Reflection and re-evaluation on resource inputs, such as water and energy for rice could generate incremental contributions at the grassroots level. Given the colossal popularity of nice rice-based cuisine in the Greater Mekong Sub-region, there is multiple benefits from the retail perspective, one, on-going quality control processes and secondly, heightened awareness. This innovation on the retail business practice would also foster good governance, societal contributions and stakeholder engagement. The East - West Economic Corridor (EEC) redefine role of interfirm networks (Tsai, \& Ghoshal, 1998) with the potential to blend of rural - urban habitats. in Cambodia, Laos, Myanmar, Vietnam and Thailand. Rurbanization is primarily a sustainable blend of power, experience and culture (Sharma, 2004). The common denominator is heritage of cultures, folklore that have significant footprint on culinary-driven behavior-interlaced family businesses (Chua, Chrisman, \& Sharma, 1999). The corridor structure, resources scale, sustainability impact enhances local cuisine skills. Self-reliance on entrepreneurship, benefits the rurbanization readiness. Rurbanization is rural - urban aligned development with characteristics of sustainability corridor that develops on social entrepreneurship (Volkmann, Tokarski, \& Ernst, 2012). This paper pegs past heritage as a cornerstone to anchor present developmental systems, such as the East - West Economic corridor as continuum. Local governance aims to open entrepreneurship along the corridor and the surrounding hinterland. Food and society present principles as well as paradoxes (Guptill, Copelton \& Lucal, 2017). Re-bonding via the heritage-cuisine is promising though the diverse sub-cultures along the economic corridor with intermittent nodes of urban spots and spaced with rural hinterland. Social media virtual connectivity along with East - West Economic Corridor geographical connectivity would surge sustainable behaviors. Sustainable use of natural resources would gain importance through the heritage-based cuisine tourism. Local wine is an essential item in the heritage cuisine menu (Sogari, Pucci, Aquilani \& Zanni, 2017). Rurban aligned economic development would benefit from the cuisine-focus. Sustainability initiatives, such as, renewable energy usage, greenhouse emissions curb, inorganic pesticides elimination, water conservation and waste optimization would be encouraged leading to a combined sustainability-linked metric that parenthesizes East-West Economic Corridor with rurbanization with heritage cuisine-led tourism as a central determinant (Sogari, Pucci, Aquilani \& Zanni, 2017).

Developmental outlays ensure economic progress, however there is a research need to local entrepreneurship and diffusion of innovation to external stakeholders. Heritage cuisine tourism can satisfy both, thereby creating tangible economic value as well as intrinsic value with respect to retaining the rich heritage through traditional cuisine. As cuisines are a function of local natural resources, the heritage cuisine tourism can contribute to equity in terms of development in urban hotspots, as well as, robust rural growth while retaining the heritage splendor. A well-defined heritage cuisine led tourism would encompass developmental infrastructural projects such as East - West Economic Corridor, as well as sustainability clusters such as rurbanization. Heritage cuisine retains the care for health, food without preservatives, community owned infrastructure, as well as, water, waste, energy optimization. Global emissions issue calls for aligned climate change mitigation, with the enhancement of trust quotient (Shi, Ma, Shao, Tang, Wang \& Wang, 2015). Heritage cuisine-led tourism adds-on to accountability for environment. This rationale guides this research paper to assess the ecological and habitat sustainability related impacts, along with economic benefits. This approach benefits policy makers to innovate rurbanbudgetary needs along the East - West Economic Corridor spanning Cambodia, Laos, Myanmar, Vietnam and Thailand (C-L-M-V-T). Heritage cuisine-led tourism serves several locales and would promote cooperation among the countries, as it provides differentiated development yet integrates sustainable 
practices. The novelty and variety-seeking behavior of the heritage cuisine tourism clientele would incessantly challenge the entrepreneurs to engage, acquire, bolster and compliment variety cuisines.

The small \& medium scale niche-rice-based heritage culinary entrepreneurial ecosystem balances the bigger industries and exporters that primarily utilize the East West Economic Corridor. However, there is ample evidence economic corridors suffer as natural resources erode, forest foliage ebbs, livability and well-being deteriorate, air quality debilitates, and societal fabric attenuates. This poses as a research gap as well as a heritage cuisine-led tourism opportunity. This recourse benefits eco-tourism through renewal of culinary education, environment-care incorporated through cuisine, cross cultural adhesion in Cambodia, Laos, Myanmar, Vietnam and Thailand and dynamically building a sustainability-linked metric (Butler \& Hinch, 2007). Developmental outlays to regenerate and restore heritage sites are sparse. To enable the entrepreneurial ability to manage heritage habitats, culinary legacy can attract tourists, that would release valuable resources for resilience of the heritage-habitats endowed with a rich biocultural/heritage diversity (Kirshenblatt-Gimblett, 1998; Moli, 2011). These resources could be deployed for developmental projects involving sustainability platforms of health, food, infrastructure, water and education that is of synergistic interest for policy makers, local tourism and cuisine providers (Gössling, Garrod, Aall, Hille \& Peeters, 2011). However, it is important to promote sustainable practices among culinary and allied entities and potentially inform sustainability measurement more widely. Maurice, G. D. S. (2017)

\section{Literature integrating low input, niche-rice heritage cuisine, East West Corridor spanning Greater Mekong Sub-region}

Rice-cuisine trails and routes sprouts amid socio-cultural novelty that are not static (Torabi Farsani, Zeinali \& Moaiednia, 2016). Heritage cuisine could be identified with the concept of museumisation (MacLeod, 2017). Undisputedly, heritage evokes from faith that evolves from a specific landscape, nostalgia coalesced to habitats and greenway projects that spur development perspectives (Balestrieri \& Congiu, 2017). Rice-based heritage cuisine routes and trails are concatenated to development models (Mesić, 2008) as is supported by route-based experience in linear resource settings (Timothy \& Boyd, 2014). Community-based tourism to augment sustainable habitat engagement would be beneficial to regional development fabric as in the case of Eastern Economic Corridor (du Cros, Hilary, 2017; Khanal \& Babar, 2007). Absolutes with respect to sustainability of a tourism trail is primarily quality of food experience, and clusters of socio-spatial activities (Boyd, 2017). The notion of cultural recycling manifests in re-living tradition and reminiscences with continuous dimension of critical reflection that enable heritage cuisine tourist cohorts' transcendence and symbolic back-casting (Baudrillard, 2017). Sustainability challenges such as food shortages to flood or drought, agricultural characteristics, chemical based fertilizers \& pesticides, impact cuisine can be addressed through the heritage cuisine-led tourism (Istasse, 2016). Destination management models set mix of demand and supply that a visitor has ease of access to a critical mass of development and satisfaction (Macleod and Gillespie, 2011). Tourism Area Life Cycle (TALC) conceptualizes a value-creating tourist destination potential through stages of waving and waning popularity incorporating environmental quality (Butler, 1980). Further deployed is the Force Field Analysis (FFA) that assess the rural - urban blended organizational cultures (Johnson, Scholes \& Whittington, 2008). Nature-based tourism is popular in Sundarbans due to scenic beauty, as also enhancing total economic value, fostering eco-system services and community livelihood (Islam, 2016). Many former mining areas have now lost their industrial function and are now turning to tourism for regional revitalization and community economic development. The transformation process of these industrial, and in some cases derelict, mining sites (Conlin \& Jolliffe, 2010).

The trails and routes literature (Mitchell \& Hall, 2006; MacLeod, 2017) is interspersed with food/cuisine/wine and tourism research (Richards, 2012; Horng \& Tsai, 2012). The embodiment of heritage evoked cuisine appeals to nutrition-seeking tourism fatigued with fewer structured meals and random snacking (Bessière, 1998). Tourists trail a corridor of linear resources frame-worked by space or habitat. When that space is embodied with heritage, it emanates a narrative or folklore. This has significant social outcomes and impacts (MacLeod, 2017). The features, attractions, nodes are coconfigured with East - West Economic Corridor, Rurbanization and Heritage cuisine tourism. (Torabi Farsani, Zeinali \& Moaiednia, 2016). There is a larger narrative built up favoring heritage-cuisine tourism 
being a catalyzer to regional integration and rural urban equity with accent on food-folklore-festivals, culinary genealogy and lineage (Trotter, 2001). Attributes that draw tourists root from commemoration and distinctiveness (Timothy, 2015, Everett, 2016).

\section{Conceptual model}

The conceptual model draws inspiration from the need to substantive scholarship in conceptual thinking on the combinatorial effect of cultural, ecological and management issues (Timothy \& Boyd, 2015). The tourist trail development process essentially has organic impetus that is drawn from heritage cuisine tourism in this paper. The potential for sustainability-linked low-inputs rice-based heritage-cuisine tourism metric portrayed with the East West Economic Corridor and Rurbanization for the Cambodia, Laos, Myanmar, Vietnam, Thailand habitat is depicted in the conceptual model (figure 1). This 'in tandem' approach has beneficial outcomes with respect to (i) incubating-stage local culinary expertise, (ii) low carbon tourism financing (iii) community-level buy-in.

Figure 1:

East - West Economic corridor modules for low-input rice-based Heritage-cuisine tourism
Low input resource parameters for ricebased Heritage-cuisine Tourism

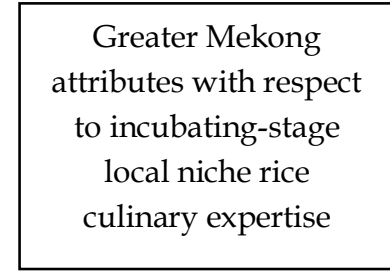

Greater Mekong ttributes with respect to incubating-stage local niche rice culinary expertise

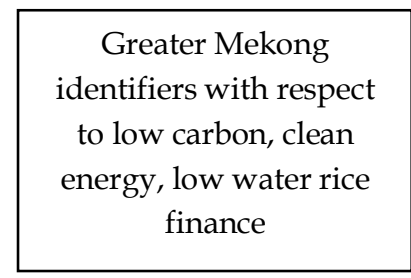

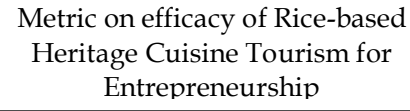
Entrepreneurship

Metric on potency of Rice-based

Heritage Cuisine Tourism for Sustaining Natural Resources

Sustainable entrepreneurship metric

Figure 1 Sustainable entrepreneurship model portrayed with the blend of East - West Economic Corridor and Rurbanization in Greater Mekong Sub-region with focus on Cambodia - Laos - Myanmar - Vietnam Thailand

The conceptual model of sustainable entrepreneurship metric (figure 1) portrayed with the blend of East - West Economic Corridor and Rurbanization in Cambodia - Laos - Myanmar - Vietnam Thailand. The model depicts the hierarchical construct of three levels of aggregation (Congdon, 2003).

Level 1 Modules and parameters (top row, figure 1): East - West Economic corridor modules and Rural - Urban connect parameters for Heritage-cuisine Tourism. The proposition at level 1 of the hierarchical construct are the economic, environmental, and societal ramifications encountered while operationalizing heritage-cuisine tourism in peripheral hinterlands (Hohl \& Tisdell, 1995).

Level 2 Attributes, Identifiers and Characteristics (second row, figure 2): Cambodia - Laos - Myanmar Vietnam - Thailand (C-L-M-V-T) attributes with respect to incubating-stage local culinary expertise, identifiers that propel low carbon tourism finance, and characteristics that generate community-level buyin. The East - West Economic Corridor is designed to surge Cambodia - Laos - Myanmar - Vietnam Thailand (C-L-M-V-T) mechanisms of innovation through nature-based tourism within a hub and periphery context (Holmgren \& Lindkvist, 2016).

Level 3 Metric on efficacy (third row, figure 1): Metric on efficacy of Heritage Cuisine Tourism for Entrepreneurship and Sustaining Natural Resources. Based on the central tenet of co-creating heritagecuisine and sustainable natural resources is a function of equitable distribution of the benefits derived 
from such tourism. An objective measure reflects community stakeholder capacity-building, development dividends and sustained efficacy (Adams, 2010).

\section{Methodological framework}

The level 1, level 2 and level 3 are causal paradigms to arrive at the sustainable entrepreneurship metric. Research propositions are drawn from qualitative processes (case-lets) to determine appropriate metrics (Nuttavuthisit, 2017; Bunmak, 2017). This methodological framework could be adapted in terms of weights on energy, water, land, waste taking into consideration the ground realities at the locale. Consequently, this methodological tool provides a degree of objectivity to preserve, conserve and safeguard of intangible cultural heritage with respect to heritage cuisine. CLMVT is hugely variant on culture thereby spawning spatial and temporal entrepreneurship (Shariff, \& Zakaria, 2011).

\section{Survey}

The true potential of heritage cuisine could be manifested effectively when broadened to the Cambodia - Laos - Myanmar - Vietnam - Thailand gourmet that is experienced best in an ethnic family setting (Brännback \& Carsrud, 2012). Tourist service providers and restaurant owners should attempt to create ambience for heritage tourists to succor the nostalgia and history associated with the heritage cuisine. Heritage values family congregation (Tables 1, 2 and 3). The survey selected tourists from developed countries. The sample rated sets of responses corresponding to the levels 1, 2, 3 of the hierarchical Bayes constructs: (1) modules and parameters (2) attributes, identifiers and characteristics (3) metric on efficacy.

Table 1:

\begin{tabular}{|l|l|l|l|l|l|}
\hline \multicolumn{2}{|l|}{$\begin{array}{l}\text { East - West Economic corridor modules with } \\
\text { respect to Rice-based Heritage Tourists }\end{array}$} & \multicolumn{2}{|l|}{$\begin{array}{l}\text { Rural - Urban connect parameters with } \\
\text { respect to niche rice Heritage tourists }\end{array}$} \\
\hline & $\begin{array}{l}\text { In } \\
\text { Developed } \\
\text { country } \\
(\mathrm{N}=120)\end{array}$ & $\begin{array}{l}\text { Visiting } \\
\text { C,L,M, V,T } \\
(\mathrm{N}=200)\end{array}$ & Age & $\begin{array}{l}\text { In } \\
\text { Developing } \\
\text { Country } \\
(\mathrm{N}=123)\end{array}$ & $\begin{array}{l}\text { Visiting } \\
\text { C,L,M,V,T } \\
\text { (N=200) }\end{array}$ \\
\hline $\begin{array}{l}\text { Below } 25 \\
\text { years }\end{array}$ & 15 & 19 & $\begin{array}{l}\text { Below } 25 \\
\text { years }\end{array}$ & 5 & 15 \\
\hline 25 to 40 years & 75 & 121 & $\begin{array}{l}25 \text { to } 40 \\
\text { years }\end{array}$ & 53 & 106 \\
\hline 40 to 60 years & 29 & 52 & $\begin{array}{l}40 \text { to } 60 \\
\text { years }\end{array}$ & 49 & 70 \\
\hline $\begin{array}{l}\text { Above } 60 \\
\text { years }\end{array}$ & 1 & 8 & $\begin{array}{l}\text { Above } 60 \\
\text { years }\end{array}$ & 16 & 7 \\
\hline $\begin{array}{l}\text { No } \\
\text { response }\end{array}$ & None & None & No response & None & 2 \\
\hline
\end{tabular}

Table 1: Respondents Age as a determinant of East - West Economic corridor modules and low resource inputs for niche rice parameters (Figures indicate number of respondents)

The gender equity is preferred to attain uniformity. The respondent tourists usually belong to nuclear family. The large family is conspicuous by its absence. The elaborate heritage dining table in C-L$\mathrm{M}-\mathrm{V}-\mathrm{T}$ is at its best when the full family is present around it. There is a sense of occasion and camaraderie. The blend of development, rurban mix and heritage dignity can re-germinate this family spirit and kinship.

Table 2:

\begin{tabular}{|c|c|c|c|c|c|}
\hline \multicolumn{3}{|c|}{$\begin{array}{l}\text { Gender attributes, identifiers and relevant to } \\
\text { low-input, niche rice-based Heritage tourism }\end{array}$} & \multicolumn{3}{|c|}{$\begin{array}{l}\text { Gender characteristics relevant to niche rice- } \\
\text { based Heritage tourism }\end{array}$} \\
\hline Gender & $\begin{array}{l}\text { In } \\
\text { Developed } \\
\text { Country } \\
(\mathrm{N}=120) \\
\end{array}$ & $\begin{array}{l}\text { Visiting } \\
\mathrm{C}, \mathrm{L}, \mathrm{M}, \mathrm{V}, \mathrm{T} \\
(\mathrm{N}=200)\end{array}$ & Gender & $\begin{array}{l}\text { In } \\
\text { Developing } \\
\text { country } \\
(\mathrm{N}=123) \\
\end{array}$ & $\begin{array}{l}\text { Visiting } \\
\mathrm{C}, \mathrm{L}, \mathrm{M}, \mathrm{V}, \mathrm{T} \\
(\mathrm{N}=200)\end{array}$ \\
\hline Male & 61 & 100 & Male & 63 & 100 \\
\hline
\end{tabular}




\begin{tabular}{|l|l|l|l|l|l|}
\hline Female & 59 & 100 & Female & 59 & 100 \\
\hline $\begin{array}{l}\text { No } \\
\text { response }\end{array}$ & None & None & $\begin{array}{l}\text { No } \\
\text { response }\end{array}$ & 1 & None \\
\hline
\end{tabular}

Table 2: Respondents Gender with respect to Attributes, Identifiers and Characteristics in Cambodia Laos - Myanmar - Vietnam - Thailand (C-L-M-V-T) (Figures indicate number of respondents)

Heritage cuisine could evolve to re-kindle the joys of family reunion, thereby having important societal value creation for East - West Economic Corridor. The sample statistics need to look different if this is to happen.

Table 3:

\begin{tabular}{|l|l|l|l|l|l|}
\hline \multicolumn{3}{|l|}{$\begin{array}{l}\text { Efficacy of niche-rice-based Heritage Cuisine } \\
\text { Tourism for Entrepreneurship }\end{array}$} & \multicolumn{3}{|l|}{ Sustaining Natural Resources } \\
\hline Status & $\begin{array}{l}\text { In Developed } \\
\text { Country } \\
(\mathrm{N}=120)\end{array}$ & $\begin{array}{l}\text { Visiting } \\
\mathrm{C}, \mathrm{L}, \mathrm{M}, \mathrm{V}, \mathrm{T} \\
(\mathrm{N}=200)\end{array}$ & Status & $\begin{array}{l}\text { In Developing } \\
\text { country } \\
(\mathrm{N}=123)\end{array}$ & $\begin{array}{l}\text { Visiting } \\
\text { C,L,M,V,T } \\
(\mathrm{N}=200)\end{array}$ \\
\hline Single & 52 & 52 & Single & 35 & 51 \\
\hline Married & 44 & 126 & Married & 59 & 115 \\
\hline $\begin{array}{l}\text { Living } \\
\text { together } \\
\text { partners }\end{array}$ & 18 & 18 & $\begin{array}{l}\text { Living } \\
\text { together } \\
\text { partners }\end{array}$ & 23 & 30 \\
\hline Divorced & 2 & 4 & Divorced & 5 & 2 \\
\hline $\begin{array}{l}\text { No } \\
\text { response }\end{array}$ & 2 & None & $\begin{array}{l}\text { No } \\
\text { response }\end{array}$ & 1 & 2 \\
\hline
\end{tabular}

Table 3: Respondents Marital Status impacting the Metric on efficacy of low-input niche rice-based Heritage Cuisine Tourism for Entrepreneurship and Sustaining Natural Resources (Figures indicate number of respondents)

The Sustainable entrepreneurship metric: assessing the modules, parameters, attributes to adapt for the hierarchical Bayes construct

Bayes' postulates the subjective theory of statistical inference, intends rationality. This paper CLMVT variants evolve from joint- or multi-habitat inferences. Based on this inductive reasoning, the application of Hierarchical Bayes (HB) Regression methodology is appropriate (Hacking, 2016). The author concedes that the axiomatic consistency is significantly difficult given the chance and subjectivity (Hacking, 2016). Incorporating system of logic (Mill, 1884), the hierarchical structure of data with respect to prior and posterior estimates (Zečević \& Kovačević, 2017), by linking the survey sample data to levels $1,2,3$, the Hierarchical Bayes construct is substantiated. This is so, as the Bayesian method allows comparisons of levels present in the model, model identifiability and convergence (Congdon, 2003). The iterated beta estimates of the sets of data hierarchy arising due to interplay of East - West Economic corridor modules and Rural - Urban connect parameters for low-input niche-rice-based Heritage-cuisine Tourism are put in the Hierarchical Bayes model for the Sustainable Heritage-cuisine tourism Intent metric. The model allows movement to blend modules, parameters, indicators to create a sustainable heritage cuisine tourism fabric for stakeholders within a hierarchical framework (Kessel, et al. 2017).

Assessing the modules and parameters with respect to East - West Economic corridor modules and low input parameters for niche-rice-based Heritage-cuisine-driven entrepreneurship:

Country variance are taken into cognizance while assessing the wide range of parameters, including lifestyle association to locale heritage to construct a gastronomic circuit along the East - West Economic corridor with rural - urban typicality (Gordin \& Trabskaya, 2013). Taking the instance of Thai Kitchen of the World international appeal, roots back to the heritage rich royal palace kitchen that perfected the art of healthy and tasty Thai food. This was emulated among the population with distinctive recipes, eating ambience, art of food decoration and arrangement. Instances from the Rattanakosin, Chakri eras evidenced Thai meals with suitable ingredients from Chinese, Mon, Lao, Burmese, Khmer, Indian, and Japanese origin, creating the international melting pot (Van Esterik, 2008). The ingenuity and elegance of Thai cuisine complement with neighboring Laos, Cambodia, Myanmar and Vietnam, that provides 
health and convenience combination for discerning international consumers. The exquisiteness of food arrangement coupled with high nutritional value with fresh taste is confirmed in this survey-based research. The modules and parameters derive international value acceptance of the Heritage-cuisine. As the East-West Economic corridor and Rural - Urban alignment flourish, Heritage-cuisine driven Tourism is poised to cater as a one-stop service to produce that would enhance tourism sustainability. C-L-M-V-T would be the agro-basket that would conform to natural resources conservation. This positioning would evolve as a natural sustainable value chain coupled with the growing integration of East - West Economic corridor countries.

Assessing the attributes, identifiers and characteristics:

Hierarchical Bayes assesses the viability of the blend (Han, Dieck \& Jung, 2017). The proposition is to calibrate the 'how' of inducting the Sustainable Heritage-cuisine tourism Intent metric with the three levels of the construct. Cambodia - Laos - Myanmar - Vietnam - Thailand (C-L-M-V-T) attributes with respect to incubating-stage local culinary expertise, identifiers that propel low carbon tourism finance, and characteristics that generate community-level buy-in are gauged. The value proposition secures sustainable use of resources as it addresses a vital research gap for blending rural with urban tourist destinations. Tourism leverages the heritage multi-cuisine in C-L-M-V-T with the backdrop of habitat development through East-West Economic Corridor in the milieu of rurbanization. It is assumed that rural - urban aligned connect would nurture heritage for well-being through the heritage-cuisine domain, as is well supported by literature. The East - West Economic corridor is characterized by an infrastructural fabric that is predominantly rural with rapid clustering urban hot-spots.

Assessing the metric on efficacy:

Metric on efficacy of Heritage Cuisine Tourism for Entrepreneurship and Sustaining Natural Resources is assessed as follows. Among the C-L-M-V-T, the East - West Economic Corridor creates renewed interest in heritage-cuisine, with emphasis on Thailand as the de facto, gateway to ASEAN. This is attributable to the healthy Thai cuisine, as also respective local cuisines in Cambodia, Laos, Myanmar and Vietnam. In this paper, the attributes, identifiers and characteristics are based on a survey where the preference for heritage-cuisine over fast food was found to be the preferred choice of international tourist clientele. Heritage-cuisine with C-L-M-V-T variants set to create a niche over the fast food international cuisine segment. Sustainable lifestyles need the nourishment of freshly cooked food that is intently bearing the heritage signature of rural - urban uniqueness.

The methodology adopted here suits the analysis of multi-level data. An initial qualitative estimate of regressors (betas) of influence at each level are estimated (Table 1) for the repeated iterations to select the most appropriate subsets of regressors for each parameter as an initial starting point for the next level iteration (Hair and Black, 2006).

Table 4:

\begin{tabular}{|l|l|l|l|l|l|l|l|}
\hline & $\begin{array}{l}\text { East- West } \\
\text { Economic } \\
\text { corridor } \\
\text { modules } \\
\text { for rice- } \\
\text { based } \\
\text { Heritage- } \\
\text { cuisine } \\
\text { tourism }\end{array}$ & $\begin{array}{l}\text { Rural- Urban } \\
\text { connect } \\
\text { parameters } \\
\text { for rice-based } \\
\text { Heritage- } \\
\text { cuisine } \\
\text { Tourism }\end{array}$ & $\begin{array}{l}\text { attributes } \\
\text { with respect } \\
\text { to } \\
\text { incubating- } \\
\text { stage local } \\
\text { niche-rice- } \\
\text { based } \\
\text { culinary } \\
\text { expertise }\end{array}$ & $\begin{array}{l}\text { identifiers } \\
\text { with } \\
\text { respect to } \\
\text { low carbon } \\
\text { tourism } \\
\text { finance }\end{array}$ & $\begin{array}{l}\text { characteristics } \\
\text { with respect to } \\
\text { community-level } \\
\text { buy-in }\end{array}$ & $\begin{array}{l}\text { Metric on } \\
\text { efficacy of } \\
\text { niche-rice- } \\
\text { based } \\
\text { Heritage } \\
\text { Cuisine } \\
\text { Tourism for } \\
\text { Entrepre- } \\
\text { neurship }\end{array}$ & $\begin{array}{l}\text { Metric on } \\
\text { potency of } \\
\text { rice-based } \\
\text { Heritage } \\
\text { Cuisine } \\
\text { Tourism for } \\
\text { Sustaining } \\
\text { Natural } \\
\text { Resources }\end{array}$ \\
\hline Cambodia & 4 & 3 & 3 & 1 & 2 & 3 & 2 \\
\hline Laos & 7 & 6 & 5 & 1 & 6 & 5 & 3 \\
\hline Myanmar & 5 & 4 & 5 & 1 & 4 & 5 & 5 \\
\hline Vietnam & 9 & 8 & 7 & 1 & 2 & 6 & 6 \\
\hline Thailand & 8 & 7 & 8 & 1 & 8 & 9 & 5 \\
\hline
\end{tabular}

Table 4: Estimated scaled data adapted from secondary data sources, survey and literature review

The Hierarchical Bayes nominal regression approach to measurement is derived from preliminary qualitative processes and cases. The pilot outcome based justifies the proposed methodological 
framework, with the Overarching Sustainability Intent metric (significance 0.004) meeting the likelihood ratio tests (Table 2). The betas are estimated on a scale one to ten (table 4) at selected locales and hotspots in Cambodia, Laos, Myanmar, Vietnam and Thailand available from literature review, sample survey and author's estimation from recent developments on East West Economic corridor, Rural - Urban connect for Heritage cuisine tourism. As depicted in the conceptual model, the first level of the $\mathrm{HB}$ iteration. Alignment of the modules, attributes and indicators (Figure 1, Conceptual model) depend on the predictor variables of level 1, incubating-stage local culinary expertise, low carbon tourism finance, and community level buy-in and level 2, entrepreneurship efficacy and sustaining natural resources. The dynamic interplay of the respective influences would lead to objective assessment of the alignment of the orthogonal dimensions (Orme, 2000). The outcome level 3 aims at the sustainable entrepreneurship metric.

Table 5:

\begin{tabular}{|l|l|l|l|l|}
\hline \multicolumn{5}{|l|}{ The Sustainable entrepreneurship metric } \\
\hline \multirow{5}{*}{} & $\begin{array}{l}\text { Model } \\
\text { Fitting } \\
\text { Criteria }\end{array}$ & \multicolumn{4}{l|}{ Likelihood Ratio Tests } \\
\cline { 2 - 5 } Model & $\begin{array}{l}\text {-2 Log } \\
\text { Likelihood }\end{array}$ & Chi-Square & df & Sig. \\
\hline Intercept Only & 21.501 & & & \\
\hline Final & 5.402 & 21.501 & 25 & .004 \\
\hline
\end{tabular}

Table 5: Excerpt of output from Hierarchical Bayes Nominal Regression for the Sustainable Low-input niche-rice-based Heritage - cuisine tourism Intent metric

The pilot outcome (table 5) upholds the value proposition with the sustainable entrepreneurship metric (significance 0.004) meeting the likelihood ratio tests. This corroborates the need to deploy heritage-cuisine-led tourism to derive modular, multi-faceted parameters of tourism along with economy, local, national and regional culture \& society (Macleod \& Gillespie, 2011). Heritage here is seen through the lens of gastronomical folklore cuisine, that connects the dots on sustainable development through East - West Economic corridor, as also spirit of equity between rural and urban habitats. The vibrant region defined by Cambodia, Laos, Myanmar, Vietnam, Thailand, may have issues, but heritage cuisine tourism can kindle togetherness, differentiated yet integrated. Habitat specific data on natural resources plugged in with collaborative heritage-cuisine actors, such as, policy-makers, local entrepreneurers, agro-forheritage-tourism community, is potentially synergistic. The Hierarchical Bayes process converges to a dynamic estimated measure of the Sustainable Heritage - cuisine tourism intent. This outcome is in consonance with emerging themes on (i) retention of uniqueness of a heritage cuisine tourist destination (ii) creates a historic and folklore image as a preferred tourist destination along a cuisine-circuit (iii) development blended with heritage perspective (Macleod \& Gillespie, 2011).

\section{Conclusion, Future Research trajectory, Limitations}

East - West Economic corridor modules and Rural - Urban connect parameters for Heritagecuisine Tourism Facets - notable - widespread types of tourism. Human societies interact with landscape that articulates heritage (Cooper, Chakraborty \& Chakraborty, 2017). Low-input, niche-rice-based heritage tourism is among the very oldest forms of travel. locations where historic events occurred - living cultures dominate - critically examine all aspects - (i) colonial heritage, (ii) commodification, (iii) interpretation, (iv) urban renewal, (v) interfaith tourism, (vi) nostalgia and folklore. Issues on rice value chain incorporate adaptable transport, advertising and marketing. This is well demonstrated with shift to rice-based agrifood system concatenating rice with maize (Mottaleb, Kruseman \& Erenstein, 2018). As global health evokes concern, urban migration proliferates, rural robustness attenuates, heritage-cuisine-led tourism can blend in with East West Economic corridor and rurbanization, to create a C-L-M-V-T kitchen of the world. Re-zoning enables bio-health. Rice value chain is transforming to diverse compatible and alinable bio-responses. This approach inoculates bio-health and retains diversity. Evidence from the Millennium Ecosystem Assessment (Scherr \& McNeely, 2007), indicates precarious exacerbation of rice-value-chain 
elemental carbon footprint issues. Local communities embed sustainable livelihoods. This termed as ecoagriculture (Scherr \& McNeely, 2007). This aspect could serve as agenda for future research on this key issue that is intricately linked with the implementability of the sustainable development goals.

\section{References}

Adams, J. L. (2010). Interrogating the equity principle: The rhetoric and reality of management planning for sustainable archaeological heritage tourism. Journal of Heritage Tourism, 5(2), 103-123.

Balestrieri, M., \& Congiu, T. (2017). Rediscovering Rural Territories by Means of Religious Route Planning. Sustainability, 9(3), 363.

Baudrillard, J. (2017) The Consumer Society: Myths and Structures, Sage, pg 120 - 121.

Bessière, J. (1998). Local development and heritage: traditional food and cuisine as tourist attractions in rural areas. Sociologia ruralis, 38(1), 21-34.

Boyd, S. W. (2017). heritage trails and tourism. Journal of Heritage Tourism, 12(5), 417-422.

Brännback, M., \& Carsrud, A. L. (2012). Thai Rolls Restaurants: Growth and Delegating Control to Nonfamily Management. In Family Firms (pp. 47-55). Springer, New York, NY.

Bunmak, S. (2017). Migrant networks of irregular Nayu workers in Malaysia-The case of the Tom Yum restaurants in Kuala Lum. Geografia-Malaysian Journal of Society and Space, 7(2).

Butler, R. W. (1980). The concept of a tourist area cycle of evolution: implications for management of resources. The Canadian Geographer/Le Géographe canadien, 24(1), 5-12.

Butler, R., \& Hinch, T. (2007). Tourism and indigenous peoples: Issues and implications. Routledge.

Cavaliere, C. (2017). 4 Foodscapes as Alternate Ways of Knowing: Advancing Sustainability and Climate Consciousness through Tactile Space. Linking Urban and Rural Tourism: Strategies in Sustainability, 49.

Chandra, P. (2009) Projects Planning, Analysis, Selection, Financing, Implementation and Review, Tata McGraw Hill, pg $4.21-23$.

Chua, J. H., Chrisman, J. J., \& Sharma, P. (1999). Defining the family business by behavior. Entrepreneurship theory and practice, 23(4), 19-39.

Conlin, M. V., \& Jolliffe, L. (Eds.). (2010). Mining heritage and tourism: A global synthesis. Routledge.

Cooper, M., Chakraborty, A., \& Chakraborty, S. (Eds.). (2017). Rivers and Society: Landscapes, Governance and Livelihoods. Routledge.

du Cros, Hilary, (2017) UNESCO in Southeast Asia: world heritage sites in comparative perspective. Journal of Heritage Tourism, 13(1), pp. 94-95

Everett, S. (2016). Food and drink tourism: Principles and practice. Sage.

Gordin, V., \& Trabskaya, J. (2013). The role of gastronomic brands in tourist destination promotion: The case of St. Petersburg. Place Branding and Public Diplomacy, 9(3), 189-201.

Gössling, S., Garrod, B., Aall, C., Hille, J., \& Peeters, P. (2011). Food management in tourism: Reducing tourism's carbon 'foodprint'. Tourism Management, 32(3), 534-543.

Guptill, A. E., Copelton, D. A., \& Lucal, B. (2017). Food and society: Principles and paradoxes. John Wiley \& Sons.

Hacking, I. (2016) Logic of Statistical Interference, Cambridge University Press,

Han, D. I., tom Dieck, M. C., \& Jung, T. (2017). User experience model for augmented reality applications in urban heritage tourism. Journal of Heritage Tourism, 1-16.

Hohl, A. E., \& Tisdell, C. A. (1995). Peripheral tourism: development and management. Annals of Tourism Research, 22(3), 517-534.

Holmgren, H., \& Lindkvist, K. B. (2016). Resource management regimes and innovation in peripheral nature-based tourism: The case of North Cape tourism and sea-fishing tourism. Norsk Geografisk Tidsskrift-Norwegian Journal of Geography, 70(4), 203-215.

Horng, J. S., \& Tsai, C. T. S. (2012). Culinary tourism strategic development: an Asia-Pacific perspective. International journal of tourism research, 14(1), 40-55.

Islam, M. S. (2016). How Worthy is the Sundarbans Mangrove Forest? An Exploratory Study. Environment and Natural Resources Journal, 14(1), 17-25.

Istasse, M. (2016) Eating in Northeastern Cambodia: a socio-anthropological approach to highland food in Ratanakiri, White Lotus Press,

Johnson, G., Scholes, K., \& Whittington, R. (2008). Exploring corporate strategy: text \& cases. Pearson Education.

Kessel, S. T., Elamin, N. A., Yurkowski, D. J., Chekchak, T., Walter, R. P., Klaus, R., ... \& Hussey, N. E. (2017). Conservation of reef manta rays (Manta alfredi) in a UNESCO World Heritage Site: Large-scale island development or sustainable tourism? PloS one, 12(10).

Khanal, B. R., \& Babar, J. T. (2007) Community based ecotourism for sustainable tourism development in the Mekong region. Policy Brief, 1, 2007.

Kirshenblatt-Gimblett, B. (1998). Destination culture: Tourism, museums, and heritage. Univ of California Press. 
MacLeod, N. (2017). The role of trails in the creation of tourist space. Journal of Heritage Tourism, 12(5), 423-430.

Macleod, D. and Gillespie, S. (2011) Sustainable Tourism in Rural Europe: approaches to development, Routledge, pg 33-89.

Maurice, G. D. S. (2017). Kyoto Cuisine Gone Global. Gastronomica: The Journal of Critical Food Studies, 17(3), 36-48.

Mesić, J. (2008). A Resource for Sustainable Development: the case of Croatia. Museum International, 60(4), 91-99.

Mill, J. S. (1884). A system of logic, ratiocinative and inductive: Being a connected view of the principles of evidence and the methods of scientific investigation (Vol. 1). Longmans, green, and Company.

Mitchell, R., \& Hall, C. M. (2006). Wine tourism research: the state of play. Tourism Review International, 9(4), 307332.

Moli, G. P. (2011). Community based eco cultural heritage tourism for sustainable development in the Asian region: A conceptual framework. International Journal of Social Ecology and Sustainable Development (IJSESD), 2(2), 6680.

Mottaleb, K. A., Kruseman, G., \& Erenstein, O. (2018). Determinants of maize cultivation in a land-scarce rice-based economy: The case of Bangladesh. Journal of Crop Improvement, 32(4), 453-476.

Nielsen, C. P. (2002). Vietnam in the international rice market. Fødevareøkonomisk Institut.

Nuttavuthisit, K. (2017). Yaowawit School Kapong. Kellogg School of Management Cases, 1-13.

Rawhouser, H., Cummings, M., \& Newbert, S. L. (2017). Social impact measurement: Current approaches and future directions for social entrepreneurship research. Entrepreneurship Theory and Practice, 1042258717727718.

Richards, G. (2012) An overview of food and tourism trends and policies. In Food and the Tourism Experience: The OECD-Korea Workshop (pp. 13-46).

Sandbrook, C. (2010). Local economic impact of different forms of nature-based tourism. Conservation Letters, 3(1), 21-28.

Scherr, S. J., \& McNeely, J. A. (2007). Biodiversity conservation and agricultural sustainability: towards a new paradigm of 'eco-agriculture' landscapes. Philosophical Transactions of the Royal Society B: Biological Sciences, 363(1491), 477-494.

Shariff, N. M., \& Zakaria, Z. (2011). Digital Mapping of Intangible Cultural Heritage: The Case of Traditional Foods. International Journal of the Humanities, 8(11).

Sharma, P. (2004). An overview of the field of family business studies: Current status and directions for the future. Family business review, 17(1), 1-36.

Sogari, G., Pucci, T., Aquilani, B., \& Zanni, L. (2017). Millennial Generation and Environmental Sustainability: The Role of Social Media in the Consumer Purchasing Behavior for Wine. Sustainability, 9(10), 1911.

Steier, L. (2001). Family firms, plural forms of governance, and the evolving role of trust. Family Business Review, 14(4), 353-368.

Timothy, D. J. (Ed.). (2015). Heritage cuisines: Traditions, identities and tourism. Routledge.

Timothy, D. J., \& Boyd, S. W. (2014). Tourism and trails: Cultural, ecological and management issues (Vol. 64). Channel View Publications.

Torabi Farsani, N., Zeinali, H., \& Moaiednia, M. (2016). Food heritage and promoting herbal medicine-based niche tourism in Isfahan, Iran. Journal of Heritage Tourism, 1-11.

Trotter, R. (2001). Heritage tourism. Special interest tourism: Context and cases. Milton, Qld: John Wiley \& Sons.

Tsai, W., \& Ghoshal, S. (1998). Social capital and value creation: The role of intrafirm networks. Academy of management Journal, 41(4), 464-476.

Van Esterik, P. (2008). Food Culture in Southeast Asia. Greenwood Publishing Group.

Volkmann, C., Tokarski, K., \& Ernst, K. (2012). Social entrepreneurship and social business. An Introduction and Discussion with Case Studies. Gabler. Wiesbaden.

Zečević, B., \& Kovačević, I. (2017). Benefit Segmentation of Outbound Summer Package Tourists. Facta Universitatis, Series: Economics and Organization, 401-414. 